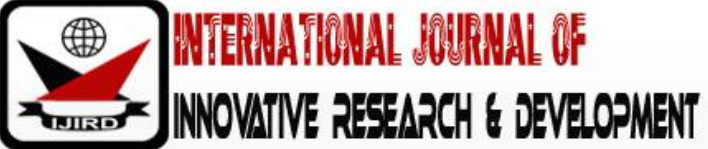

ISSN 2278-0211 (Online)

\section{Effect of High-Performance Work Practices on Organizational Performance of General Hospital, Mubi, Adamawa State, Nigeria}

Mohammed Nasiru
M.Sc Student, Department of Business Administration,
Adamawa State University, Mubi, Nigeria
Ushiwa D. Kwabe
M.Sc Student, Department of Business Administration,
Adamawa State University, Mubi, Nigeria

\begin{abstract}
:
It is imperative to note here that, element of high performance includes incentives, compensation, participation of employees in decision making, fringe benefits, performance allowances, etc. All of these directly or indirectly affect the performance and intention of employees to stay in an organization and yet are not addressed. The main objective of this study is to examine the effect of high-performance work practices on organizational performance of General Hospital, Mubi, Adamawa state. The study adopted the use of non-experimental design with specification in survey research design. The population of the study comprises both senior and junior staff totaling (344) members of staff, while the sample size is 185 determined using Yaro Yemani formula. Hypotheses was tested using Pearson correlation analysis, the decision is that there is significant relationship between the variables under study since $(r=0.339,0.983$, 0.939 and $P$-value $\leq 0.000$ and $d f=4)$. The finding revealed that organization has experience high employee turnover due to lack of employee participation in decision making, lack of employee participation in decision making has led to low employee productivity in the organization, this has led the organization to experience inequality decisions and weak employee attachment to organization. In addition, the study therefore, recommends that the Management of General Hospital Mubi should develop a strategies that will enable the hospital has experience lower employee turnover i.e. through allowing employee to participation in decision making, also should allow employee to participation in decision making in order to achieve high employee productivity in the hospital, this will enable the organization to experience quality decisions and strong employee attachment to organization.
\end{abstract}

Keywords: Effect, general hospital, high performance, organizational and work practice

\section{Introduction}

Companies' business operation in the new economic world is becoming more complicated due to growing globalization and market liberalization, rising consumer needs, and ever-increasing market rivalry. Hence, companies are continuously in search of ways to improve efficiency and competitiveness. In general, human resources, both as a workforce and as a business function, are treated as the highest operating cost that should be minimized and a source of higher efficiency at the same time. In the last four decades, human resources (HR) and other management practices have changed dramatically due to globalization, privatization / deregulation, competition and technological advances. These highly turbulent changes in the environment have forced organizations to adopt new practices in the workplace that improve sustained high-performance levels. Such methods have taken the attention of both practitioners and academics in recent years, and are increasingly being used by Fortune 1000 companies (Harmon, Scotti, \& Behson, 2003).

Those practices or processes were conceptualized as high-performance organizational activities (also referred to as strategic HR goals in the related literature, engagement work systems, high-performance work systems, highperformance organizations and high-commitment management) Consisting of flat hierarchical structures, job rotation, self-managed teams, employee participation in decision-making, horizontal communication channel, skill-based pay systems (Handel and Gittleman, 2004).

Pearce (2010) Compensation implies a compensation structure where the employees who perform better are paid more than the average employees who perform better. Armstrong (2005) Compensation Management deals with the formulation and implementation of strategies and policies aimed at compensating people fairly, fairly and consistently according to their value to the organization. Employees are generally recognized as a critical part of the business tool, with the ability to improve the sustainable competitive advantage of the organization. An organization can gain a competitive advantage and achieve its objectives by making good use of its employees (Price, 2004). 
It is a self-generated urge that comes from an employee's inside and influences him / her in working harder. They are linked to job-related and social benefits such as opportunities to use one's skill, interesting jobs, acknowledgement of good results, opportunities for advancement, a sense of accomplishment and achievement, involvement in decisionmaking and careful and compassionate treatment etc. Extrinsic motivation, on the other hand, derives from innate psychological needs such as the need for integrity and autonomy when activity is conducted to achieve externally imposed incentives (Kasser \& Ryan, 2000). A large body of literature supports the notion that an organization's work practices influence the sentiments of commitment and satisfaction of individual employees towards an organization. Among these activities are those involving open communication, organizational investments in preparation, decision-making and engagement of individual workers, advancement opportunities and the use of results contingent rewards (Meyer \& Allen, 2009). Employee satisfaction is thought to be one of a well-run organization's main necessities and is believed by all corporate management to be essential. It is undeniable reality that the future of business depends on the level of employee satisfaction. Dissatisfied employees only cause immediate problems for their particular enterprises. High performance HRM practices provide a number of important sources of improved performance for companies (Pfeffer \& Veiga, 2002).

\section{Statement of the Problem}

At the same time, employees are important elements of the achievement of the organizational goals, and hence of organizational survival. The explanation essentially rests on the fact that workers are operators and are in better position to know the challenges they face in performing a specific task and how best to solve them. The problem lies mainly in the fact that obtained participation was not clearly understood as well as its benefits. (Harmon, Scotti, \& Behson, 2003). It is imperative to note here that, element of high performance includes incentives, compensation, participation of employees in decision making, fringe benefits, performance allowances, etc. All of these directly or indirectly affect the performance and intention of employees to stay in an organization and yet are not addressed (Torrington, 2002). Some managers believe that their sole prerogative is the decision-making process and should be treated as such. Yet again, top executives tend to stay aloof from their staff to create an all-important air around them. Therefore, the purpose of this study is to determine employee participation in decision-making, incentives and empowerment at General Hospital, Mubi, in order to determine the benefits and problems resulting from such practices.

The study sought to answer the following research questions in order to achieve the study objectives:

- What is the effect of employees' participation in decision-making on organizational performance in General Hospital, Mubi?

- What is the effect of incentives packages on organizational performance in General Hospital, Mubi?

- What is the effect of employees' compensation on organizational performance in General Hospital, Mubi?

\subsection{Research Hypotheses}

- $\mathrm{H}_{0}$ : Employees participation in decision making does not have any significant effect on organizational performance in General Hospital, Mubi.

- $\mathrm{H}_{0}$ : Incentives packages do not have any significant effect on organizational performance in General Hospital, Mubi.

- $\mathrm{H}_{0}$ : Employees compensation does not have any significant effect on organizational performance in General Hospital, Mubi.

\section{Conceptual Clarifications}

\subsection{Concept of High-Performance Practices}

In this context, the concept of high-performance work practices is considered strategically important in two different areas: a) developing and maintaining core competencies, and b) as a necessary condition for the implementation of organizational strategy (Torrington, 2002). High-performance work practices are considered as an organizational strategy to manage the relationship of employment. As a special combination of practices, high-performance work practices aim to increase the productivity of employees by maximizing their skills, motivation, commitment, communication, involvement and flexibility. The impact of high-performance work practices on the organizational performance is achieved through three basic elements: 1) increasing the employees' knowledge, skills and abilities, 2) employees' empowerment and participation in decision making and problem solving and 3) motivating employees through incentives to make additional discretionary work effort (Armstrong, 2008). As a strategic employee management approach, high-performance work practices are away from the scientific management and bureaucratic work organization of the Taylor and create conditions for the identification of employees with organizational objectives. They show the extent to which the firm invests in the best human capital possible and also show the value and importance of this capital as a source of sustainable competitiveness (Takeuchi, 2009). High-performance work practices embody multidimensional design, and the concept of their components (dimensions) is often focused on the analysis of four sub-functions: selection, preparation, assessment, compensation (Boxal, \& Purcell, 2000). A broad community of activities (dimensions) includes the three essential elements of high-performance work activities. High-performance work practices improve the expertise, talents and abilities of workers through comprehensive recruiting, strategic hiring, training, role design and skill creation compensation. Practices like incentive pay, performance evaluation, internal promotion, job protection, flexible work schedules, grievance procedures and high salary are opportunities that inspire and engage. But even knowledge, skills and motivation will not allow employees to make discretionary efforts unless the organizational structure and job design 
create the necessary conditions through participation programmes, self-management teams, information sharing and job security.

\subsection{Employee Participation in Decision Making}

According to Northouse (2004), employee participation in decision making (EPDM) has its roots in management's "theory Y" perspective. Therefore, he suggests that employees are fundamentally interested in performing well at work and will be more attached and committed to a work organisation, if their seniors' value their contributions in making decisions that affect the nature of the work. Although the effects of EPDM may vary with the nature of participation, it has been found that higher levels of EPDM are positively related to higher levels of organizational commitment, lower turnover of employees and higher performance of employees. EPDM can also lead to better labor-management relations, stronger attachment of employees to organizations, better quality decisions and better performance (Elele \& Fields, 2010)

EPDM as a Human Resource practice acts as a signal to employees that management values their contribution. In their review of employee participation assessment, Elele \& Fields (2010) Noted that employees will most often have more comprehensive knowledge of their work than even senior or supervisors. Decisions will be made with more information in consultation with the employees. Employees who eventually engage in decision taking are best prepared to enforce certain decisions. Employees may also perceive their managers as valuing their contribution, or as admitting that employees are smart. This can lead to employee satisfaction and ultimately higher productivity. Cotton, (2000) Categorized EPDM as: direct employee involvement with management in making work-related decisions, consultative participation where employee opinions are taken into account by decision-makers, part-time employee ownership of the organization, and representative participation through a union or staff association.

\subsection{Organizational Performance}

Organizational performance is a sign of how well an enterprise fulfills its objectives. Organizational efficiency is one of the most important constructs in managerial research $(\mathrm{Ho}, 2008)$. Most researchers used the term performance to describe the set of measurement of input and output production and transactional efficiency in terms of describing organizational performance (Shahzad, Luqman, Khan, \& Shabbir, 2012). Consequently, the ultimate aim of any company is to achieve superior performance (Bhatti, Khan, Ahmad, Hussain, and Rehman, 2011). Measuring and assessing the success of organizations thus play an important role in transforming organizational targets into practice (Popova and Sharpanskykh, 2010). Organizational performance includes the actual productivity or result of a business that is calculated in contrast to its intended productivity or targets and objectives. Organizational performance has been described as the ability of the organization to achieve its objectives and goals with the help of talented administration, good governance and constant rededication to achieve business goals (Mahapatro, 2013).

\subsection{Incentives Packages}

Specific companies set up compensation programs to recognize and reward employee success that meets expectations. Incentive packages are financial or non-financial incentives provided to workers in order to motivate them to make greater efforts in any given task (Arnolds and Venter, 2007). "High output can be measured by the willingness of workers to work, and therefore workers who are not well-rewarded produce less. "Luthans (1998) separated these rewards into monetary incentives and non-monetary incentives, also known as financial or non-financial incentives. In the meantime, workers may be driven internally or extrinsically. Intrinsic motivation is an inward drive that comes from within the person, which makes him work effectively and efficiently towards organizational productivity realization (Ryan \& Deci, 2000). Suitable incentives have been described as one of the ways by which organizations can motivate and increase the output of their employees. In the literature, there are many studies examining monetary and non-monetary incentives and their impact on organizational variables (Al-Nsour, 2012; Scheepers, 2009). In the meantime, incentives are designed to provide workers with optimum performance and help retain the most efficient among them (Arnold, 2013).

\subsubsection{Monetary Incentives}

Monetary benefits are used by labor employers to attract their best brains and to reward them for a well-done job and monetary performance excellence (Nelson, 2003). The reward can come in several forms: regular wage, benefits, pensions, income sharing, pension plans, employee stock, overtime pay, participation incentives, competition and competitions, output-oriented merit raises, performance rewards, piecework, safety incentives, recommendation awards etc. (Cole, 2002). Monetary incentives are used to define incentive-payment programs that explicitly or indirectly ties rewards to the productivity level (Kepner, 2001).

\subsubsection{Nonmonetary Incentives}

Nonmonetary incentives are to reward employees through opportunities for outstanding job performance. This typically comes in the form of more encouraging authority, prizes, management engagement, advancement, holidays, improved work climate, written appreciation, presents, formal dinners, casual gatherings, plaques, etc. (Ellis and Pennington, 2004).

\subsection{Compensation Policy}

Compensation is the human resource management mechanism that deals with any form of compensation individuals earn in return for carrying out organizational tasks, with the desired outcome of an employee drawn to the work, happy and driven to do a good job for the employer (Ivancevich, 2004). It could be financial rewards referring to any 
monetary rewards which go beyond and beyond basic pay. These rewards are added separately and not into the basic salary. Examples of these include financial, bonus, and recognition incentives. Compensation can be defined as direct and indirect compensation earned by employees in an organization that contributes to the satisfaction and retention of employees and improves performance (Adeniji \& Osibanjo, 2012). Direct compensation includes performance-based wages, wages, bonuses or commissions, overtime work, holiday premiums, whereas indirect compensation is paid as medical benefits, housing allowances, meal allowances, utility allowances, incentive bonuses, shift allowances, hospitality expenses, out-of-station allowances, vehicle loan benefits, annual leave allowances, basic car allowances, etc. The design of compensation plans is critical in personnel management because of its direct effect on the satisfaction and performance of the employees in the company (Adeniji \& Osibanjo, 2012).

\subsection{Effect of High-Performance Work Practices on Organizational Performance}

One of the main SHRM research goals is to establish a clear link between the HR practices and organizational performance. The results of many extensive researches confirmed that a higher level of efficacy of SHRM creates higher performance results. A Combs meta-analysis reveals that there are 92 studies (19 319 research organizations) up until 2006 that provide specific statistics for high-performance work activities and success relationships. In addition to the empirical studies in which organizational performance was assessed by objective metrics as a criterion variable, there is one important category of studies in which the subjective managerial interpretation of success in relation to competitors in the industry is used as performance indicators. One of the first of these inquiries was that of Delany and Huselid, where a strong correlation of selectivity in hiring, training and incentive rewards with perceptive performance measures was found (Pfeffer, 2005).

\subsection{Effect of High-Performance Practices on Job Satisfaction}

High value Human Resource Practices have gained significant attention in recent years as the source of competitive advantage in today's word 's dynamic climate. The aim of high-performance human resource management is to improve corporate performance through the assistance of its employees (Armstrong, 2001). According Bamberger and Meshoulam (2000) high performance human resource practices consist of three main parts: (1) people flow, including selective staffing, training (such as more extensive, general skills training), employee mobility (for example, broad career paths, promotion within the firm) and guarantee of job security; (2) appraisal and rewards, including performance appraisal (specifically long- term, results- orientated appraisal), compensation and other benefits, such as extensive, openended rewards; (3) employment relations, including job design (such as broad job descriptions, flexible job assignments) and encouragement of participation. Delaney, Huselid, Dow Scott, Bishop and Chen (2003) summarize that, HRM best practices are aimed at enhancing overall employee performance within the company, resulting in improved organizational success. Delaney, Huselid, Dow Scott, Bishop and Chen (2003) continue to state that commitment plays an important role in best practices of HRM. As a result, the employer's commitment to areas such as training and development is reciprocated by the employee, with this increased commitment to the organisation, performance increases as employees are more skilled and committed to the profession, resulting in a 'win - win' situation for both parties.

\subsection{Effect of Employee Participation in Decision Making on Organizational Performance}

There is growing evidence that firm performance increasingly rests on employee involvement in decision-making (Spreitzer \& Mishra, 1999). Scholars argued that employee involvement contributes to organizational efficiency because it has the capacity to enhance decision-making quality by increasing inputs and fosters commitment to decision-making outcomes in in the workplace (Markey, 2006). According to Spreitzer (1999), Workers with a greater choice as to how to do their own work have been found to have a high level of job satisfaction and hence high performance. A significant relationship has also been established between frequency of employee consultation and organizational commitment (Noah, 2008).

\subsection{Effect of Incentives on Organizational Performance}

Employee attitudes such as satisfaction are not a major determinant of job performance (Spector, 2003), but contribute to (or discourage) absenteeism, waste reduction, industrial accidents, and help to build the organization's culture. Incentives paid periodically to an employee / worker for service of labour in production. Thus, payment to labour is generally called wages. Wages often apply to the hourly rate of production and maintenance paid to classes such as. Salary normally refers to the rates paid periodically to clerical workers (Ogunbameru, 2004). Remuneration offers more than a way to meet the physical needs-it provides recognition, a sense of achievement and social status. The formulation and administration of wages and salaries to recruit and keep the right employees in the right place is therefore the management's primary duty in every organization (Ogunbameru, 2004).

\subsection{Effect of Employee's Compensation on Organizational Performance}

According to Gomez and Gerhart (2012), compensation for employees is the single most important cost in most firms, accounting for 60 per cent of total cost in some manufacturing organizations. Nevertheless, in some service companies this is much higher and this means that the efficiency with which compensation is distributed will make a big difference in gaining or losing competitive advantage. The same is true of Dessler (2008), who says that it is critical for every organization and its employees to establish a good employee compensation plan. Also, Amstrong (2008) notes that one of the goals of reward management is to motivate people and get their commitment and commitment. According to Dessler (2008), there are many factors that impact the design of any compensation program, including legal requirements, 
union pressures, business strategies and strategic competitive goals, and lastly internal and external equity. In order to fully understand how any organization determines its employee compensation plan, it is necessary to examine how employee compensation plans are classified, the factors used to determine the compensation plans and the compensation plans process.

\section{Empirical Review}

In a study of the relationship between trust, HR practice and organizational performance, a sample of 275 organizations in Israel confirmed that organizations investing more in training, using a performance-based compensation system, encouraging employee participation and using the internal labor market show significantly higher levels of organizational performance. We may infer from all this that the most effective way of allocating the money and increasing efficiency within the company is by paying for performance programs (Tzafrir, 2005). One study in France looked at 28 organizations and found that there is a strong statistical association between HR activities (recruitment, promotion, training and growth, performance evaluation, compensation) and the relative organizational performance index (Cerdin \& Som, 2003). Further confirmation of the assertion that high-performance work practices have a significant impact on the perception of organizational performance is obtained from Eurofond research conducted in multinational samples in EU and other European countries. One of those are EPOC survey and European Company Survey 2009.

The impact of workers on labor organization and work climate was analyzed in the EPOC survey (Wood, \& De Menezes, 2008). The results showed that the participation of employees has huge positive effects on behavior and on economic performance. 2009 European Business Survey is using data from 27,160 companies. The study was conducted on the basis of this survey about HR practices and performance relationships. Four performance indicators were used: working climate, lack of HR problems, productivity of labour, and economic condition of organization. The five work practices groups are: flexible working hours, financial incentives, training, autonomous teams and employee voice. The implication is that creative job methods have a beneficial impact on the different output dimensions.

\section{Theoretical Framework}

\subsection{Incentives Theories}

Individual employees are motivated by various incentives or benefits and it is important to know how motivated they are and what can satisfy them in order to encourage them to have the right attitudes to work which will invariably improve employee performance and organizational productivity. The incentive theory is one of the major theories of motivation and suggests that employees are motivated to do things out of a desire for incentives (Bernstein, 2011, Hockenbury \& Hockenbury, (2003). Maslow (1954) concluded that workers are driven to satisfy five rates of need: physiological needs, protection needs, need for belonging, self-esteem and self-actualization, needs are usually satisfied by appropriate salaries and attractive reward packages. Griffin (1999). Hertzberg (1959) concluded that satisfaction and dissatisfaction are motivated by various factors; motivation and hygiene factors and the motivation and dedication of employees to work are proportional to the satisfaction of the employees. Consequently, incentives are intrinsic drive which compels individual employees to achieve personal and corporate goals (Hockenbury \& Hockenbury, 2003). He added that motivation factors are instrumental to employees' willingness to

Perform optimally and this gives people rewards, such as job results, appreciation, promotional opportunities. These motivating factors are considered to be fundamental to the employees' job performance.

Vroom's Theory of Expectancy (1964) claimed that motivation depends primarily on the assumptions of individuals regarding their willingness to perform certain activities in anticipation of expected and proportionate rewards (Daft, 2003). The basis of the motivation expectation theory is the relationship between commitment, success and outcomes, the imputation of the employees decides the incentive package. Expectancy theory suggested that individual or group effort contributes to success, and the result of their success is correlated with their bundled rewards Sequel to the above, incentive packages are a motivating drive that enhances the right attitudes of employees to work and will invariably encourage them to commit and work hard in anticipation of what they are expected to achieve in return for the impute.

Psychologists classify the basic needs of human beings into five levels that correspond to the "hierarchy of needs" of Maslow. From the perspective of management and personal psychology, compensation should satisfy the medical, health and security needs of the first two levels, as well as the social contact, self-esteem and self-actualization needs of an employee. Tsai (2004) Suggested that if all of these needs can be met, employees will be at ease to work. A lot of studies therefore argue that absence rate and job satisfaction are closely related. Effective rewards (e.g. a full attendance reward and bonus) can be adopted to improve employee satisfaction to reduce employee absence and increase job performance.

\section{Methodology}

The researcher adopted the use of non-experimental design with specification in survey research design. This study was carried out in General Hospital Mubi. The population of the study comprises both senior and junior staff totaling (344) members of staff. Yamani (1964) formula was used to draw the sample size for the study, which is calculated as follows:

$\mathrm{n}=\frac{\mathrm{N}}{1+\mathrm{N}(\mathrm{e})^{2}}$

$\mathrm{n}=344$

$\mathrm{n} \quad=\quad 344$ 


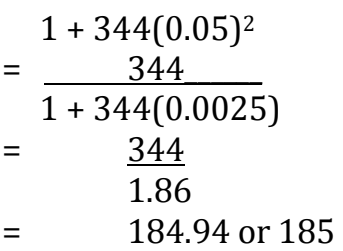

Therefore, the sample size for this study is 185 .

The study makes used of questionnaire as one of tools for collecting data. Questionnaire is a research instrument consisting of a series of questions and other prompt for the purpose of gathering information from respondents. And also, the researcher employed to use of secondary data for literature. The questionnaire was designed on five-point Likert scale ranging from strongly agreed (5), Agree (4), Undecided (3), Disagreed (2) and strongly disagreed (1). Also, the study employed the use of the qualitative methods of data collection. The methods of data analysis used were percentage analysis to address the research questions, while the hypotheses are tested using regression analysis at 0.05 level of significance.

\section{Analysis and Results}

\subsection{Hypotheses Testing}

\subsubsection{Hypothesis I}

- $\mathrm{H}_{0}$ : Employees participation in decision making does not have any significant effect on organizational performance in General Hospital, Mubi.

\begin{tabular}{|l|c|c|l|}
\hline \multicolumn{3}{|c|}{ Correlations } \\
\hline \multirow{3}{*}{ EPDM } & EPDM & OP \\
\cline { 2 - 4 } & Sig. (2-tailed) & 1 & $.339^{* *}$ \\
\cline { 2 - 4 } & $\mathrm{N}$ & 176 & .000 \\
\hline \multirow{3}{*}{ OP } & Pearson Correlation & $.339^{* *}$ & 176 \\
\cline { 2 - 4 } & Sig. (2-tailed) & .000 & 1 \\
\cline { 2 - 4 } & $\mathrm{N}$ & 176 & 176 \\
\cline { 2 - 4 } & \multirow{3}{*}{ T* Table 1 Correlation Is Significant at the 0.01 Level (2-Tailed) }
\end{tabular}

A Pearson's correlation analysis was conducted to examine the relationship between employee participation in decision making and organizational performance in General Hospital, Mubi. The result of correlation revealed positive relationship existing between variables, a correlation of 0.339 and significant at 0.00 , which is less than 0.5 level of significant. Therefore, we reject the null hypothesis and accept the alternate which state that employees' participation in decision making have a significant effect on organizational performance in General Hospital, Mubi.

\subsubsection{Hypothesis II}

- $\mathrm{H}_{0}$ : Incentives packages do not have any significant effect on organizational performance in General Hospital, Mubi.

\begin{tabular}{|l|c|c|c|}
\hline \multicolumn{3}{|c|}{ Correlations } \\
\hline \multirow{3}{*}{ IP } & IP & OP \\
\cline { 2 - 4 } & Pearson Correlation & 1 & $.983^{* *}$ \\
\cline { 2 - 4 } & Sig. (2-tailed) & 176 & .000 \\
\hline \multirow{3}{*}{ OP } & N & $.983^{* *}$ & 176 \\
\cline { 2 - 4 } & Pearson Correlation & .000 & 1 \\
\cline { 2 - 4 } & Sig. (2-tailed) & 176 & 176 \\
\hline
\end{tabular}

Table 2

**. Correlation Is Significant at the 0.01 Level (2-Tailed)

A Pearson's correlation analysis was conducted to examine the relationship between incentive packages and organizational performance in General Hospital, Mubi. The result of correlation revealed positive relationship existing between variables, a correlation of 0.983 and significant at 0.00 , which is less than 0.5 level of significant. Therefore, we reject the null hypothesis and accept the alternate which state that incentives packages have a significant effect on organizational performance in General Hospital, Mubi. 


\subsubsection{Hypothesis III}

- $\mathrm{H}_{0}$ : Employees compensation does not have any significant effect on organizational performance in General Hospital, Mubi.

\begin{tabular}{|c|c|c|c|}
\hline \multicolumn{2}{|c|}{ Correlations } \\
\hline \multirow{3}{*}{ EC } & EC & OP \\
\cline { 2 - 4 } & Pearson Correlation & 1 & $.939^{* *}$ \\
\cline { 2 - 4 } & Sig. (2-tailed) & 176 & .000 \\
\hline \multirow{2}{*}{ OP } & N & $.939^{* *}$ & 176 \\
\cline { 2 - 4 } & Pearson Correlation & .000 & 1 \\
\cline { 2 - 4 } & Sig. (2-tailed) & 176 & 176 \\
\hline
\end{tabular}

Table 3

**. Correlation Is Significant at the 0.01 Level (2-Tailed)

A Pearson's correlation analysis was conducted to examine the relationship between employees' compensation and organizational performance in General Hospital, Mubi. The result of correlation revealed positive relationship existing between variables, a correlation of 0.989 and significant at 0.00 , which is less than 0.5 level of significant. Therefore, we reject the null hypothesis and accept the alternate which state employee's compensation have a significant effect on organizational performance in General Hospital, Mubi.

\subsection{Findings}

After the collected data for this study were pooled together and analyzed below;

- The results revealed that organization has experience high employee turnover due to lack of employee participation in decision making, lack of employee participation in decision making has led to low employee productivity in the organization, this has led the organization to experience inequality decisions and weak employee attachment to organization, also employees most often will not have complete knowledge of their work, because is only their senior or supervisors that participation in decision making.

- Findings shows that staffs of General Hospital, Mubi are not given housing allowance, medical and health insurance allowance, traveling/vocation allowances, free meal and vehicles in order to achieve effect organizational commitment.

- Finding also revealed that there is no employee compensation that will help in gaining competitive edge among staff, there is no equitable compensation system to increases employee morale, no strong recognition for employees and their services provided, no adequate and fair compensation and lastly most of the staff social needs are not provided to them in order to enhance their quality work-life in General Hospital, Mubi.

\section{Conclusions and Recommendations}

The first research hypothesis was to assess whether employee's participation in decision making does not have any significant effects on organizational performance in General Hospital, Mubi. To effectively test this hypothesis, all the relevant variables were put together and subjected to analysis through correlation statistical tool to ascertain the nature and level of the effect. The outcome of the analysis shows that there is positive relationship existing between variables, a correlation of 0.339 and significant at 0.00 , which is less than 0.5 level of significant. Which further revealed that organization has experience high employee turnover due to lack of employee participation in decision making, lack of employee participation in decision making has led to low employee productivity in the organization, this has led the organization to experience inequality decisions and weak employee attachment to organization.

The second research hypothesis of this study was to examine whether incentives packages do not have any significant effect on organizational performance in General Hospital, Mubi. After a comprehensive relevant analysis, the result of correlation revealed positive relationship existing between variables, a correlation of 0.983 and significant at 0.00 , which is less than 0.5 level of significant. In addition, the study concludes that staffs of General Hospital, Mubi are not given housing allowance, medical and health insurance allowance, traveling/vocation allowances, free meal and vehicles in order to achieve effect organizational commitment.

Furthermore, the third research hypothesis was to examine whether employee's compensation does not have any significant effects on organizational performance in General Hospital, Mubi. After a careful analysis, findings in that respect identified that the result of correlation revealed positive relationship existing between variables, a correlation of 0.989 and significant at 0.00 , which is less than 0.5 level of significant. In addition, finding also revealed that there is no employee compensation that will help in gaining competitive edge among staff, there is no equitable compensation system to increases employee morale, no strong recognition for employees and their services provided, no adequate and fair compensation and lastly most of the staff social needs are not provided to them in order to enhance their quality work-life in General Hospital, Mubi.

Arising from the findings of this study and consequent upon these and other issues examined in the study, the following recommendations are made.

- The Management of General Hospital Mubi should develop a strategies that will enable the hospital has experience lower employee turnover i.e. through allowing employee to participation in decision making, also should allow 
employee to participation in decision making in order to achieve high employee productivity in the hospital, this will enable the organization to experience quality decisions and strong employee attachment to organization, also the management should ensure that employees most often have complete knowledge of their work, information should not be restricted and strictly to only their senior or supervisors when it comes to decision making.

- The management of General Hospital, Mubi should ensure that their staff enjoys housing allowance, medical and health insurance allowance, traveling/vocation allowances, free meal and even provided with vehicles as form of incentives in order to achieve effect organizational commitment.

- Management of General Hospital Mubi should understand that employee compensation that will help in gaining competitive edge among staff, also by providing equitable compensation system will increases employee morale, there should be strong recognition for employees and their services provided, in addition, adequate and fair compensation and all the staff social needs are should be provided to them in order to enhance their quality worklife in General Hospital, Mubi.

\section{References}

i. Adeniji, A. A. \& Osibanjo A. 0. (2012). Human Resource Management: Theory and practice, Pumark.

ii. Al-Nsour, M. (2012). Relationship between incentives and organizational performance for employees in the Jordanian Universities. International Journal of Business and Management, 7(1), 78-89.

iii. Armstrong, M. (2001). Strategic Human Resource Management: A Guide to Action. Kogan Page, London.

iv. Armstrong, M. (2005). Strategic Human Resource Management: A Guide to Action. Kogan Page, London.

v. Armstrong, M. (2008). Strategic Human Resource Management: A Guide to Action (4th edition), Kogan Page: London and Philadelphia, 2008.

vi. Arnolds, C. \& Venter, D. (2007). The strategic importance of motivational rewards for lower-level employees in the manufacturing and retailing Industries. SA Journal of Industrial Psychology, 33(3), 15-23.

vii. Bamberger, P. \& Meshoulam, I. (2000) Human Resource Management Strategy, Thousand Oaks, CA: Sage.

viii. Bernstein, D. A. (2011). Essentials of psychology. Belmont, CA: Wadsworth.

ix. Bhatti, W. A., Khan, M. N., Ahmad, A., Hussain, N., Rehman, K. (2011). Sustaining Competitive Advantage through effective knowledge management, African Journal of Business Management 2011; 5(8), 3297-3301.

x. Boxal, P. \& Purcell, J. (2000). Strategic Human Resource Management: where have we come from and where should we be going, International Journal of Management Reviews, 2(2), 183-203.

xi. Cerdin, J. \& Som, A. (2003). Strategic Human Resource Management Practices: An Exploratory Survey of French Organizations, Research Center: France.

xii. Chen, S. C., \& Quester, P. G. (2006). Modeling store loyalty: perceived value in market orientation practice. Journal of service marketing, 20 (3), 188-198.

xiii. Cole, G. A. (2000). Personal Management, London, Letts Educational. Aldine Palece.

xiv. Cotton, J. (2000). "Employee participation: diverse forms and different outcomes", Academy of Management Review, 13 (1), 8-22.

xv. Delaney, C., Huselid, G. Dow, S., Bishop, J.W. \& Chen, X. (2003). An Examination of the Relationship of Employee Involvement with Job Satisfaction, Employee Cooperation, and Intention to Quit in U.S.-Invested Enterprises in China, International Journal of Organizational Analysis, 11(1): 3-19.

xvi. Dessler, G. (2008). Human Resource Management. Upper Saddle River, NJ: Pearson/Prentice Hall.

xvii. Elele, J. \& Fields, D. (2010). Participative Decision Making and Organizational Commitment: EmpoweringEmployees. shtml (Empowering Employees).

xviii. Ellis, L. \& Pennington, S. (2004). Should leaders have tusks or fangs? Management Today, 20(9), 32-33.

xix. Gomez, C. \& Gerhart, B. (2012). Compensation Strategy and Organisation performance. San Francisco, CA: JosseBass.

xx. Griffin, R. (2002). Management, Boston Houghton Mifflin Co.

xxi. Handel, M. J. \& Gittleman, M. (2004). Is There a Wage Payoff to Innovative Work Practices? Industrial Relations, 43 (1), 67-97.

xxii. Harmon, J., Scotti, D. J. \& Behson, S. (2003). Effects of High-Involvement Work Systems on Employee Satisfaction and Service Costs in Veteran Healthcare. Journal of Health Management, 48 (16), 393-418.

xxiii. Hockenbury, D. H. \& Hockenbury, S. E., (2003). Psychology. New York: Worth Publishers.

xxiv. Ivancevich, J. M. (2004). Human resource management, New York.McGraw-Hill/Irwin, 9.

xxv. Kasser, T., R. \& Ryan, M. (2000). Further examining the American dream: Differential correlates of intrinsic and extrinsic goals. Personality and Social Psychology Bulletin (22), 280-287.

xxvi. Mahapatro, B. B. (2013). Organization performance. Human resource management, 272- 279.

xxvii. Markey, R. (2006). The Internalization of Representative Employee Participation and its Impact in the Asia Pacific. Asia Pacific Journal of Human Resources, 44(3), 342- 363.

xxviii. Meyer, J. P. \& Allen, N. J. (2004). Commitment in the workplace: Theory, research, and application", Thousand Oaks, CA. Sage Publishing, Inc.

xxix. Nelson, B. \& Spitzer, D. (2003). The 1001 Reward and Recognition field book: the complete guide, workman publishing. New York.

xxx. Noah, Y. (2008). A Study of Worker Participation in Management Decision Making Within Selected Establishments in Lagos, Nigeria. Journal of Social Science, 17 (1): 31-39.

xxxi. Northouse, P. G. (2004). Leadership: Theory and Practice, Sage Publications, Thousand Oaks, CA. 
xxxii. Ogunbameru, O. A. (2004). Organizational Dynamics. Spectrum Books Ltd, Abuja.

xxxiii. Pearce, L. (2010). Managerial Compensation Based on Organisational Performance. Journal of Industrial Relation, (52). 3-28.

xxxiv. Pfeffer, J. \& Veiga, F. J. (2002). Putting people first for organizational success. Academy of Management Executive, 13(2):37-48.

xxxv. Pfeffer, J. (2005). Producing Sustainable Competitive Advantage through the Effective Management of People, Academy of Management Executive, 19, (4), 95-106.

xxxvi. Popova, V. \& Sharpanskykh, A. (2010). Modeling Organizational Performance Indicators, Information Systems Journal 2010; 35(4), 505-527.

xxxvii. Price, A. (2004) Human Resource Management in a Business, Context. 2nd Edition. London: Thomson. Robbins.

xxxviii. Ryan, D. (2000). The "what" and "why" of goal pursuits: Human needs and the self-determination of behavior. Psychological Inquiry 11 227-268.

xxxix. Scheepers, K. (2009). Using Economic Incentives to encourage Conservation in Bioregions in South Africa. ERSA Working Paper No. 120 (April).

xl. Shahzad, F., Luqman, R. A., Khan, A. R., \& Shabbir, L. (2012). Impact of Organizational Culture on Organizational Performance. Interdisciplinary Journal of contemporary research in business, (9).

xli. Spector, P. E. (2003). Industrial and Organisational Psychology, Research and Practice (3rd Ed.). New York: John Wiley \& Sons. Inc.

xlii. Spreitzer, G. M., \& Mishra, A. K. (1999). Giving UP Control Without Losing Control: Effects on Managers' Involving Employees in Decision Making. Group and Organization Management, 24(2), 155-187.

xliii. Takeuchi, R. (2009). Trough the looking glass of a social system: cross-level effects of high-performance work systems on employees' attitudes, Personnel Psychology, 62,1-29.

xliv. Torrington, D. (2002). Human Resource Management" (5 ${ }^{\text {th }}$ edition), International edition: Prentice Hall/Financial Times.

xlv. Tsai, J. H. (2004). Study on Influence of Business Internal E-Service on

Employee Satisfaction -Using IC Packing \& Testing Industry in

Nanzih Export Processing Zone as an Example, master's thesis, Graduate Institute of Business Administration, National Sun Yat-sen University.

xlvi. Tzafrir, S. S. (2005). The relationship between trust, HRM practices and firm performance, International Journal of Human Resource Management, (16)1600-1622.

xlvii. Wood, S. \& De Menezes, L. (2008). Comparing perspectives on high involvement management and organizational performance across the British economy, The International Journal of Human Resource Management, (19) 639-682. 